\title{
A look back along the canal
}

\author{
by J.S. MeNown \\ Professor of Civil Engineering \\ University of Kansas
}

Canals came into being in a world without railroads and with so few good roads that those built by the Romans stood out as the only important all-weather highways until very recent times. In such a world, the canal was a transportation miracle. In 1834, still the hey-day of the canal, an anonymous Englishman wrote of the Elegante Messagère, a canal boat on the Ostend-Bruges canal,

"There was never a cleaner or betted-fitted packet boat: the little cabin with its beautiful sofas, mirrors and chairs, rivalled the nicest drawing room: ... the boat was drawn by two horses at $4 \mathrm{mph}$, and the charge for the trip was 2 francs, which included breakfast."

What were the origins of canals? The traces go all through recorded history. Ancient milestones are prehistoric efforts to by-pass the cataracts along the Nile, the Royal Canal of Babylon, a Suez Canal over 2,000 years old and the Great Canal of China built over many centuries. Then came the impressive systems of locks and canals in medieval times in the lowlands of Western Europe and the remarkable Erie Canal in the early 1800s. And they bring us down to the Panama Canal and the abortion of the trans-Florida canal in this century.

Technical steps in the history of the canals were the improvement of natural river channels, their modest extension by digging channels to connect natural waterways, the use of ephemeral obstructions to produce slack water, the locking of river craft, and the development of viaducts and tunnels to convey canals across the countryside. Although great advances have taken place in the last century and a half, these are primarily increases in size and speed. Only a few major canals, such as part of the
St Lawrence Seaway and the connecting link between the Volga and Don Rivers in the USSR have been built during the last 30 years. The only really novel developments which can be called creations of the twentieth century are the ship elevators and inclined planes built during the last decade in Belgium, USSR and France; they carry ships in lock-like containers which move up and down on sloping rails or simply move a wedge of water along an inclined plane.

The first canal built expressly for transportation may have been the one around the first cataract on the Nile about the middle of the third millenium BC, some 4,500 years ago. The canal thus served to expedite the passage of ships in the vicinity of the recently completed and enormous Aswan Dam. The challenge provided by the proximity of the Red Sea and the Nile, not the Red Sea and the Mediterranean, produced what may have been the first link between two otherwise unconnected bodies of water. This early Suez Canal brought shipping directly from the Red Sea to the busy Nile; it could hardly have bypassed what was then the center of the western world, as does the modern Suez Canal. The task of constructing it was apparently picked up and laid down by many people, several of them important historical figures. Necho, the second king of the 26th Egyptian Dynasty, who ruled about six centuries BC, attempted to re-excavate an ancient canal connecting the eastern arm of the Nile in the delta distributaries to the Red Sea. So he was not the first. Nor did Necho complete the project. A major deterrent was a soothsayer's dire prediction giving credence to the fear that the Red Sea was higher than the lower Nile, and that such a canal would flood lower Egypt. Darius was involved with this project according to a stone given the date $510 \mathrm{BC}$ by archeologists. Finally and rather uncertainly, two his- 
torians refer to the reign of Ptolemy II of Philadelphos (in the third century BC) and to his engineers who constructed what would be the first lock of all time at the Red Sea end of this canal. A double door was built to stop the force of the tides in the Red Sea and enable ships to pass from the canal to open water. Was it a lock?

Various sources contain statements placing the first lock in China in the 10th Century AD, in Holland in the 12th, in Italy early in the 14th and, of course, in ancient Egypt three centuries BC. Was it six centuries ago or twentytwo? A decision as to whose claim is correct may depend upon the definition of what constitutes a lock and certainly depends on interpretations of skimpy and unreliable information.

The canal from the lower Nile to the Red Sea is a case in point. The canal may have been dug initially by the Pharaohs in the second millenium BC. Then came the work in the 6th century $\mathrm{BC}$ which left the canal unfinished. Or was it the re-excavation that was unfinished? If Ptolemy II built something like a lock near the Red Sea in the 3rd Century BC, the canal must have been completed before then. Finally, for this early Suez Canal, we learn that Moslem invaders destroyed it in the 7th Century AD. When was it first opened, during which periods did it operate and did it have a lock?

The account of locks in the Great Canal of China are less fuzzy, but in this case the concept of the lock was different. The structures employed were the outgrowth of a device for improving ship operation in open rivers. Low dams were built across the river and they backed up the water so as to produce slack regions over rapids or where otherwise the currents would be too strong. When a ship reached the barrier, a gate was opened and the ship squirted through if going downstream. If headed upstream, it was hauled through with great difficulty against a rapid but localized current. For dams without gates, the ship was pulled over the dam on skids.

These dams were usually placed every few miles as needed, but in 984 an engineer named Ch'iao brought two of them within 80 meters of each other and the result was a lock in effect. With proper gate manipulation, a ship could pass from one level to another while remaining in slack water; the intermediate chamber was a slice of the river extending across its entire width. Inexplicably, the Chinese neither used their invention much nor developed it further.

Little doubt remains that a conventional lock was built on the River Reie leading from the sea to Bruges in Flanders in the 12 th Century. One source puts it at Damme about 1180. Another lock was built on a canal near Bruges in 1236. These were built, not to overcome rapids on a river or to cross a divide between river basins, but rather to help a ship accommodate to the large tides in the British Channel. Low-landers have fought the ocean there since they first began to live near the sea, and a canal connected to a sea whose level could change 6-10 meters a day presented problems. Other early locks were built near Amsterdam and Haarlem in the first part of the 13th Century.

The final act in the charade of first locks was played in Northern Italy in the 15 th Century. Because an Italian engineer named Alberti wrote good accounts that have survived, he his sometime called its inventor; he may well have reinvented the lock. He built the first Italian locks near Bologna in 1439. Then Visconti improved them by adding small openings in the gates covered by "paddles" to aid with the filling and emptying. These were easier to open than the large gates and allowed the levels to equalize before the lock gates themselves were opened. Early gates had been lift gates which, although counterweighted, were difficult to move when the water levels were different. Then in the latter part of that century a renowned civil and military engineer, one Leonardo from Vinci (who also painted) wrote of building six locks for the Duc of Milan in the decade just prior to the discovery of America (the Columbian one). Leonardo invented gates which pivoted at the side, made an obtuse angle when closed so as to withstand more easily the hydrostatic forces exerted on them, and opened into recesses in the walls so as to provide a smooth passageway for the ships. Gates like these are still widely used on the world's smaller canals.

A last comment on firsts in the construction of locks takes us to North America. No one claims that the lock was invented there, and the first lock was built much later, just before the end of the 18th Century. Strangely enough, a small lock was built well inland, at Sault Ste Marie in Michigan, about the same time several others were being built near the East Coast. The early explorers, trappers and military campaigners depended heavily on the Great Lakes for transport. Hence, in 1798 someone constructed a canal which was only a mile long and had one small lock; it allowed ships with drafts of one and a half feet to pass from Lake Superior to Lake Huron. Although this lock was destroyed by American troops in 1814, the system was repaired later, and, in various versions, continued to grow in size and importance and still serves.

A few lines from an anonymous British poet are a fitting close to a discussion of early locks:

\section{“... a rare device they see,}

But newly made a waterwork; the locke

Through which the boates of Ware doe passe with [malt.

This locke contains two double dores of wood, Within the same cisterne all of Plancke, Which only fils when boates come there to passe By opening of these mightie dores."

The historic mile posts of canal development often relate to the prominent figures who were associated with them. The early Egyptian canals date back some four or five thousand years from the present, some say much more, and these canals involved the early Pharaohs and Darius. One writer calls the Nahrwan on the Tigris River "the greatest canal of antiquity", and Nebuchadnezzar was involved with it at one stage; Herodotus wrote of these wondrous technical adventures. Nero tried unsuccessfully to cut the narrow Isthmus of Corinth, and another Aegean canal was cut for Xerxes' Persian fleet. Kubla Khan finished the Grand canal of China after more than 1,000 years had gone into its development. That so many famous names are associated with particular achievements suggests that the best-known inland waterways were those that were associated with wellknown historical figures. Perhaps other such feats may have been lost to modern ken because they had no Darius or Leonardo? 
After the developments in ancient times, the pages of history contain no significant developments in the western world for more than a thousand years. The Romans built no important canals, the Arabs exerted a negative influence in the Suez, at least, and the dark ages in Europe were as dark for inland waterways as they were for progress in other fields. Only in China was there any real progress in the first millennium $A D$ and, at 1,000 years for one canal, even a grand one, the rate of progress must have been unimpressive. The leap is really from antiquity to the middle ages-from the pre-Roman era to systems still in operation. During the canal era, roughly 1500 to 1850 , thousands of kilometers of canals were built in western Europe, Russia, England and the eastern part of the States and Canada. Some examples from France typify the early part of this development, and the tall tales of "canawling" on the Erie in up-state New York describe another.

Various developments, besides the lock, made these new canals more useful. The Babylonians used trestles to support canals many feet above ground level, but their purpose was to maintain a desired level, or a slope as for the Roman supply aqueducts. With the advent of locks, a specific level was no longer required. However, as canals began to go across country like modern highways, aqueducts were essential to avoid excessive locking and to cross swamps and small water courses. Then as now, too much water threatened to flood the systemtoo little made it useless. The early planning of water resources involved the supply of water to the high points of the system and complicated systems of drainage to allow excess water to cross the line of the canal.

The Languedoc Canal, later replaced by the Canal du Midi, connected the Mediterranean Sea near Montpellier to the Garonne River near Toulouse. It was a remarkable engineering achievement. Many rulers including Emperor Augustus and a succession of French kings looked longingly at this shorter, safer route, and some even started work. However, all found it infeasible until the time of Louis XIV when its promoter, a man of property named Ricquet, and a "mathematician" named Andreóssy combined forces in the latter part of the 17th century. After "going to school" on the works of da Vinci, the latter solved problem after problem with ingenuity as he devised a supply system which is still in use, built a circular three-level canal at a river crossing and constructed what was probably the first canal tunnel. It was an outstanding piece of engineering and Andreóssy evidently deserves credit he did not receive even in his own day.

Other early tunnels were as much as two and three miles long, and because they were long, they were also dark. The opening of one of these on the St. Quentin Canal near Bellenglise in Northern France was the scene of a confrontation between the barge operators and the System. As the barges approached the tunnel on the first passage one day in 1642 , their captains declined, one after another, the privilege of being the first to enter that small dark hole in the hillside. The concern that all felt was simply that they could not see where it came out, and they wondered whether it came out at all. Some were suspicious that it might lead them down into the bowels of the earth from whence they would never return. Persuasion and reason having proved to be ineffectual, the officials resorted to bribery. They offered toll-free pas- sage in perpetuity to the first boat to make the passage. One captain finally volunteered. Whether courage or thrift was his primary motivation will never be known. As he went through the canal, the others climbed over the divide and were at the other end to cheer the first glimpse of his light as he came through. His vessel then traveled the French canals toll free for 240 years until 1880 when tolls were eliminated; its special value gone, the barge was finally put out to pasture. One can picture generations of thrifty northern Frenchmen keeping the boat operable, even though it meant rebuilding it piece by piece down through the years.

The first of the modern canals were geared to a day when speeds depended upon the speed afoot of man or animal. They took over from a system in which only small loads could be carried on mule back or in horsedrawn wagons. Small as the early barges were by modern standards, the 50-100 tons that they could carry dwarfed all of the available alternatives. The drafts ranged from one to two meters except near the ocean. The common trapezoidal section with flat side slopes established its practicality quite early. The mid-section with its uniform depth provides for passage of the ships, and the gentle slopes of the sides protect the earthwork from erosion. Surface widths between 10 and 30 meters were common. The size had to be such that two of the larger craft of the day could meet and pass, then as now.

Propulsion was a rope pulled by man or animal walking the ubiquitous tow paths, as still happens on stretches of the otherwise defunct Chesapeake \& Ohio Canal near Washington, D. C. Resistances are small at speeds of two or three miles per hour, and the number of tons that a horse or a mule can pull at his laden walking speed is phenomenal. With no rough places or hills to navigate, and no mud holes to become mired in, a new canal was truly a transportation marvel. Adam Smith in his Wealth of Nations, writing in the era before railroads and at a time of enormous difficulties with poor highways and imperfect vehicles, stated that "navigable canals are among the greatest of all improvements." And a New Englander wrote in 1820:

"All canals are... roads... on which one horse will
draw so much as thirty horses on the best turn-
pike road; or which one man alone will transport
as many goods as three men and eighteen horses
usually do on common roads."

The early tunnels presented special problems because they had no tow paths. They also had limited head room. A hole large enough for the canal and barge was triumph enough! Some of the early craft were propelled by the operators lying on their loads and walking the boat along gaining purchase for their feet on the roof or the inward sloping walls of the tunnel. Later, ropes or chains were installed, and finally the tunnels were widened sufficiently for the tow path.

European countries built thousands of miles of canals and then enlarged many of them, mostly before 1850 . The Netherlands led the way, but Belgium, France, Germany, Austria-Hungary and England each had over 1,500 kilometers of dug canals besides many more thousands of navigable rivers. Stimulated originally by Peter the 
Great, European Russia ultimately built the most remarable network in the world. Italy despite its early contributions had less geographical opportunity, but it did produce some 500 kilometers of canals, principally in the Po Valley to the north and east. Historians give Spain more brickbats than compliments on its development of inland waterways. Early Moorish accomplishments were allowed to deteriorate after the Spanish had taken over the country and one author wrote of the "blockheadedness of the Spaniard" shown in the following decree of the State Council:

"...if it has pleased God that these rivers should have been navigable, $\mathrm{He}$ would not have wanted human assistance to have made them such... it would violate the decrees of providence to improve His waterways."

The lands of Europe, India and parts of China are flatter than that in the States and hence more favorable to the development of networks of canals and rivers. Large river valleys in the States are usually separated by high and continuous mountain chains. In contrast, all of Holland and Belgium and a large part of France are below 150 meters of elevation. The divide between the Rhone flowing south, the Seine flowing west and the Rhine flowing north is less than 300 meters above sea level. Also a short and unremarkable canal near Nurnberg connects the head waters of the Danube to a tributary of the Rhine, thus linking the western European system to the Black Sea.

Russia, has a striking complex of lakes, seas, canals and rivers. West of the Ural mountains the backbone of this network is the Volga River. With heard waters only a few kilometers from the Baltic Sea, this artery flows eastward north of Moscow and then south to the Caspian Sea. On its way it passes within 80 kilometers of the Don River, to which it was connected by the VolgaDon Canal completed in 1952. The Don and the Dnieper, as well as the Danube, empty into the Black Sea. These, the Baltic Sea and the Arctic Ocean are interconnected so that one can go by sizable barge from Moscow to both of the southern seas and to the Baltic Sea and the Arctic Ocean, in season, of course. One can also go by barge from Moscow to Paris or to Marseille via the Black Sea and canals and rivers.

The Russian network is truly immense, because the really big rivers in Russia-the Ob, the Yenisei and the Lena-are east of the Urals. The system crosses the Urals from the eastern branch of the Volga and descends to the Ob, goes from the latter's head waters to the Aral Sea by canal, and it follows the upper $\mathrm{Ob}$ to Lake Baikal and on to the east. This remarkable system is all the more important because heavy transport by railroad and highway was virtually non-existent in Russia prior to 1950, and remains limited.

One additional project, the Erie Canal, was a delightful product of Yankee ingenuity. In its time and place, it too was a marvel. When it was conceived, the country was sparsely settled and recently impoverished by the War of 1812. There were no engineers and little experience. Yet the youthful State of New York set out to build one of the longest canals the world has ever seen across swamps and wilderness, and the project began and succeeded in the face of vituperative criticism and strenuous opposition. People reacted then as one might now if someone were to propose spending tax money to build a bridge across the Atlantic Ocean.

We had men of vision who had long seen the need for better transportation between the Ohio Valley and the East Coast, George Washington prominent among them. Traffic between the coast and the hinterland was increasing. The flow of settlers to upstate New York and across the divide into the Ohio Valley was already significant. But the successful farmers who had produce to sell were unable to get it to the market, and their needs for goods of all sorts went largely unmet-all because of poor transportation. A family or a ton of freight took at least a month to go from New York City to Buffalo, and heavy goods were packed and stored and portaged time and again before they arrived. Costs and damage were commensurately high.

Jefferson jealously favored the Potomac route and stated taht the Erie Canal was "A splendid project (that) may be executed a hundred years hence," and he went on to call "talk of making a canal three hundred and fifty miles long through a wilderness... little short of madness."

Although the tenor of the time was broadly favorable to better transport, each community wanted its own route to be the one, canal supporters fought against turnpike backers, and money was scarce. The St. Lawrence was a foreign competitor. Virginians split their interest between a canal along the Potomac and developments on the James River. Philadelphians were planning an overland link to the Susquehanna and Juniata Rivers and to what eventually became a remarkable dry crossing of the divide to the Allegheny and Ohio Rivers. Baltimore and Boston saw themselves losing out.

New York's route was geographically the best by far. The Mohawk Valley was a prehistoric outlet for the Great Lakes. Geologic changes shifted the outlet and created the Falls at Niagara, but the earlier geologic time left behind a clear and comparatively easy path for a water route. The divide between Buffalo on Lake Erie and the finger lake region was so low that it could be surmounted without locks and the Catskills had been cut by the Hudson River. By contrast, any other crossing of the Alleghenies required impracticably large lifts, impossibly long tunnels or transshipment by means of rails. Only the Erie Canal was really feasible.

Early discussions, legislative bills and surveys shortly after the Revolution came to naught. Just prior to the War of 1812, the Federal Government had funds in reserve and the Canal's proponents were hoping for a federal grant to bail them out, then even as now! But the War left the Government in debt; the burden returned to the State of New York. Even within the State, opinion was fragmented. Many wanted a direct connection to Lake Ontario north from Syracuse. New York City's politicians stupidly opposed the entire project, apparently being unaware that it was to help make the city the greatest port and economic center in the wolrd; the southern countries saw no gain to them, and eastern New York felt that western New York was taking advantage of it. In 1814, the Canal's opponents in the Legislature rescinded a prior authorization of the right to float a 
$\$ 5$ million loan for the Canal. Neither the political nor the physical path was easy.

Finally late in 1815 , Clinton, then as he had been for some time, Major of the City of New York, held a meeting which appointed a small committee. This group also led by Clinton produced a report which was submitted to the populace. It squelched the Ontario route and at one point chided those who would impede progress:

"Delays are the refuge of weak minds, and to procrastinate on this occasion is to show a culpable inattention to the bounties of nature, a total insensibility to the blessings of Providence, and an inexcusable neglect of the interests of society."

And at another point,

"It remains for a free state to create a new era in history, and to erect a work, more stupendous, more magnificent and more beneficial than has hitherto been achieved by the human race."

That committee did not lack eloquence, and this famed "memorial", as the report was called, was discussed at town meetings all across the State.

Of $1,500,000$ people in the State, 100,000 let their support be known; the Legislature was forced to respond. After a bitter struggle early in 1816 and lasting a month, it passed an "Act for improving the Internal Navigation of the State" and allocated $\$ 20,000$ to the Board of Commissioners for a survey. The money needed for construction was to come from various sources: donations of cheap land (including swamp and dense forest); tolls to be collected later; taxes on lotteries, auction sales and salt; a tax of one dollar on each person who traveled more than 100 miles by Hudson River steamboat; and loans. Later, if necessary, an additional $\$ 250,000$ could be raised by a land tax. The cost was initially estimated to be \$5-6 million.

The line that the Erie Canal traverses divides naturally into three sections of which the easternmost was by far the most difficult. Most of the 180-meter climb from Albany on the Hudson to Lake Erie occurs in the easternmost 160 kilometers. And the first part, between Albany and Schenectady where the level rises 70 meters in 40 kilometers is the steepest of all. The middle section is comparatively flat, dropping about 13 meters from the flat section between Utica and Syracuse into the lake country. Lesser rises but ones that are steep and rocky occur near Rochester and Lockport to complicate the western section. The planners prudently decided to build the middle section first, and it was between Utica and Rochester that canal building came of age in the young United States. In 1818, more than 2,000 men and 1,000 animals were enlisted in the fight against swamps, forests and all sorts of construction problems, not to mention epidemics of "swamp" fevers.

The laborers, many of them described as "Wild Irish bog trotters," established the Irish as indispensible for construction work. They dug most of the canals of that era. Working under contract in independent small groups, knots of men cleared a swath 60 feet wide, and dug a canal that was 40 feet wide at the top, 28 feet wide at the bottom and 4 feet deep, and it went all the way across the State of New York. They also built 77 locks with lifts of seven to ten feet and numerous bridges and aqueducts. In places, the forests were so dense that they had trouble seeing the lines of stakes. In others the swamps were so difficult to traverse that they worked while the ground was frozen. In the process, Yankee ingenuity produced a series of innovations; the small contractor, the horse-drawn scraper for moving dirt, the deep blade for cutting roots, a dumping wheelbarrow and an ingenious stumppuller were among them. European engineers who viewed the canal later were bemused by the evidence that Americans were never long deterred by a difficult or unusual task. If they did not know how, they still made do-sometimes with remarkable ingenuity.

The first celebration came in October of 1818 when water was fed into the Canal at Rome to fill the section from Rome to Utica. A citizen watching from a bridge declared the rising water to be "...a sight which could not but exhilarate and elevate the mind." People came from all sides, and crowds formed near the towns. A boat named Chief Engineer of Rome was the first vessel on the Canal. Pulled along by one horse, it carried Clinton and the other commissioners, "attended by many respectable gentlemen and ladies," from Rome to Utica, and back again the next day. "The scene", according to a reporter, "was truly sublime". One can sense how the project had captured the enthusiasm of those who watched it grow.

By the end of 1818,150 kilometers had been completed at a cost of about $\$ 1$ million: $\$ 6,000$ per kilometer for the easier miles. By 1822 , even in the middle segment unconnected at either end, 1800 boats were operating on the Canal over a distance of 350 kilometers. To prove that the canal had come of age, a speed limit was imposed that year. Fast passenger boats operating at a "breakneck velocity" of some $5 \mathrm{mph}$ led to the setting of a speed limit of $4 \mathrm{mph}$, unless the operator had written permission signed by a majority of the canal's commissioners. Two to three kilometers per hour was the conventional speed for laden barges.

What then of the difficult rock work to be done at Lockport to the west, and the 100 meters of descent from Utica to Albany? The opinion of the cracker-barrel pessimists was that, "We shall never see it finished, but our children may," Clinton, then Governor, faced hostile Republican majorities in both houses, and his many opponents launched all kinds of attacks-on him, on the Canal and on the sources of funds. Popular support was, nonetheless, equal to the task of keeping the legislature in line. The project marched forward at a pace faster than even its strongest proponents had predicted. The canal was completed in October of 1825 , a little over eight years after construction began. One chronicler wrote, with some hyperbole,

"these neophytes built the longest canal in the world, in the least time, with the least experience, for the least money, and to the greatest public benefit."

The Canal was characterized as "the first American school of engineering." The cost over-run was about $40 \%$, but at $\$ 8$ million, the canal was still a bargain. 
The Canal's opening, grumbled one nakedly envious writer from a non-Canal city, was "celebrated with (the) eclat, pompous show and parade (of the) triumphal games and processions that were given to... the Roman Emperors." Preparations taking months produced the greatest series of celebrations America had ever seen. A flotilla of boats, led by Clinton in the Seneca Chief, in. cluded a Noah's Ark named the Lion of the West. The latter-day ark carried "two eagles, two fawns, one bear" (why not two?) and many "creeping, crawling and flying things" typical of the west.

As the Seneca Chief, pulled by four gray horses, left the dock in Buffalo, a cannon signalled their departure. Sim ilar cannons, some of them captured from the British in the fighting on the Lakes, had been stationed at intervals of approximately 20 kilometers all the way to Albany and down the Hudson to New York. As each gunner heard the gun of his neighbor to the west, he fired his. In this way the departure was signalled to New York via "gun telegraph" in 80 minutes; from there, the signal was returned in like manner.

The flotilla took nine days to reach New York. On eight of the nine nights there were fireworks, oratory, banquets and balls. At Schenectady, however, the atmosphere was funereal. The Cohoes Falls had made that city a port to the west, and its citizens were certain that the Canal was to bring about its economic ruin. In contrast, the City of New York had finally seen the light. The Canal had already brought it prosperous times, and its entire citizenry plus 30,000 visitors met the flotilla on the morning of November 4, 1825. A keg of water brought from Lake Erie was poured into the ocean along with vials of water from such distant rivers as the Ganges, the Nile and the Orinoco. The celebrations were gargantuan. Later, medals were struck and designs for pottery and wallpaper reflected the canal craze. The names De Witt and Clinton were bestowed on babies, boats, locomotives and anything else one could christen. The $\mathrm{Ca}$ nal had connected the Great Lakes to the Atlantic Osean and had signalled a boom the likes of which the young country had never seen.

This Canal, though small by modern measures, produced results which may well be beyond our ken. It directed the movement of large segments of our population, created cities, made fortunes and contributed enormously to the growth of our country in the middle part of the 19th Century. Syracuse, Rochester and Utica became boom towns not unlike those mining towns in the west where gold was discovered a few years later. One demographer noted that, in 1930, seven million of New York States' ten million people lived within a few miles of the Canal system, in which he included the other elements of the waterway of which it was the major link Its economic success and the benefits to the lands and the people it served were beyond the dreams of its most ardent supporters. Trade and income from tolls grew so fast that talk of enlarging the Canal began only a few years after it was completed. Income so far outran costs that it soon became a prime source of graft.

The social setting comes down to us in legend and song. The profits to be made brought profiteers, and decisions reached by force or chicanery were by no means uncommon. The toughest crews were the first through the locks, and in case of doubt, they proved their case with fists and knives. The Erie Canal impressed people with a mixture of awe and disgust. These reactions are reflected in a passage from Moby Dick written about 1851:

"For 360 miles, gentlemen; through the entire breadth of the State of New York; through numerous populous cities and most thriving villages; through long, dismal, uninhabited swamps, and affluent cultivated fields, unrivalled for fertility; by billiard-room and bar-room; through the holyof-holiest of great forests; on Roman arches over Indian rivers and especially, by rows of snowwhite chapels, whose spires stand almost like milestones; flows one continual stream of Venetianly corrupt and often lawless life".

The success of the Erie Canal caused several other canals to start up during the 1820's. Most of these were unsuccessful. They were too costly or too late or both. Most like the Chesapeake and Ohio were never finished. The parts that were finished served for 50 to 75 years before falling into disuse. Failure usually followed the devastation of a flood when the lack of reserve capital made it impracticable to rebuild washed out dikes. But not the Erie. The tolls paid for the replacement of wooden locks by stone ones, paid off much of the debt and created a reserve for the Canal's enlargement. In 1835, just 10 years after completion, enlargement began-from $40 \mathrm{ft}$. wide to 70 , from $4 \mathrm{ft}$. deep to 7 , and from loads of 80 tons to 350 .

At the time it was to be enlarged, one debate centered on how big to make it. During discussions in the Legislature, one proponent of greater size supported his position with a salty comment:

"Might just as well dig a complete canal, same way if you're going to get married. You might just as well marry a pretty girl as an ugly one, especially if you're going to be home much".

For all its early successes, the seeds of the Canal's economic downfall were already being sown at the time of its construction. In England, the railroad was just coming into use. On July 4, 1828, the B \& O laid the "cornerstone" of a railroad whose cars were, it was then thought, to be pulled by horses all the way to the Ohio River. Not only did the railroads take more successfully to steam power, they also fought a devastating fight against the canals. With no intent to cooperate, the railroads bought up canals and allowed them to lapse into disuse, they fixed rates so as to overcome the comparative rate advantage of the canal and they used a monopolistic approach to wipe out the small barge owners who were the backbone of 'canawling'.

A letter written in 1829 about the railroads' threat to canals was republished during the unsuccessful campaign in 1971-72 for the US venture into supersonic transport. The Governor of New York wrote to President Andrew Jackson as follows:

"Dear Mr. President: The canal system of this country is being threatened by the spread of a new form of transportation known as railroads. The Federal Government must preserve the canals for 


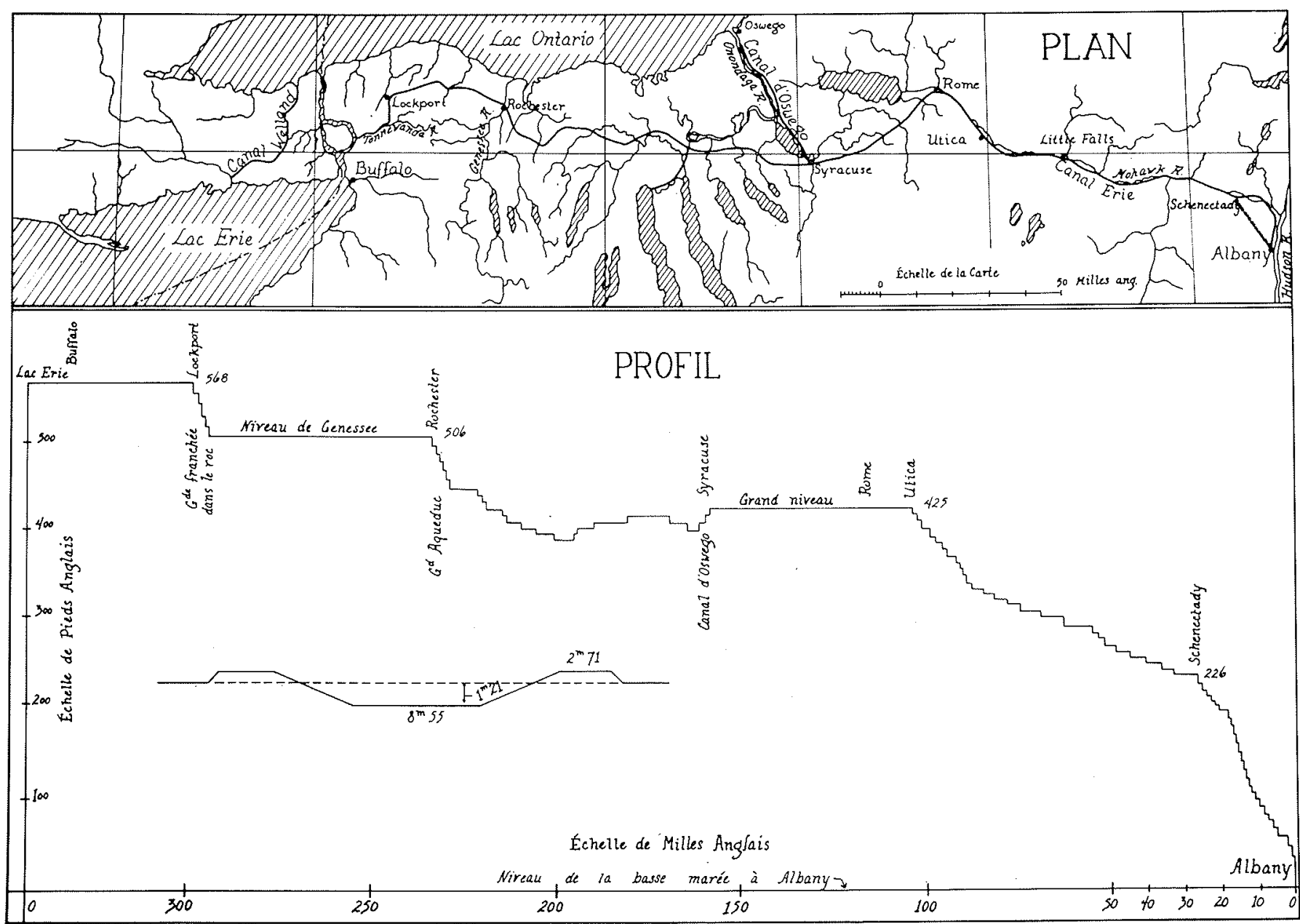

1/ Map redrawn from map. on p. 134 in Historic Highways, Vol. 14, A. B. Hulbert (1904). Credit for the original to Poussin, "Travaux d'améliorations intérieures... des Etats-Unis d'Amérique de $1824 \%$, Paris (1834).

the following reasons: 1) If canal boats are supplanted by railroads, serious unemployment will result. Captains, cooks, drivers, hostlers, repairmen and lock tenders will be left without means ô livelihood, not to mention the numerous farmers now employed in growing hay for horses. 2) Boat builders would suffer, and towline, whip and harness makers would be left destitute. 3) Canal boats are absolutely essential to the defense of the United States. In event of the expected trouble with England, the Erie Canal would be the only means by which we could ever move the supplies so vital to waging modern war.
"For the above mentioned reasons, the government should create an Interstate Commerce Commission to protect the American people from the evils of railroads and to preserve the canals for posterity. As you may know, Mr. President, railroad carriages are pulled at the enormous speed of 15 miles per hour by engines, which, in addition to endangering life and limb of passengers, roar and snort their way through the countryside, setting fire to the crops, scaring the livestock and frightening women and children. The Almighty certainly never intended that people should travel at such breakneck speed". 